\title{
An Assessment of the impact of Compensation Plan on workers Performance of selected Quoted Food and Beverages Manufacturing Companies in Nigeria.
}

\author{
Oladejo M.O ${ }^{1} *$ Yinus Oluwaseun ${ }^{2}$ \\ ${ }^{1,2}$ Department of Management and Accounting, Faculty of Management Sciences Ladoke Akintola University of \\ Technology Ogbomoso, Oyo State, Nigeria
}

\begin{abstract}
Evidence from the literature showed that in a competitive environment a successful organization must establish a compensation philosophy that will motivate the organization employee. The extent to which employee have benefited from the compensation plan system in food industry has not received much attention in developing economy such as Nigeria. Testing the Vroom expectancy theory that emphasizes the needs for organizations to relate rewards directly to performance in Nigerian foods and beverages industry will provide empirical evidence in the Nigerian context. It was in line with this that the study aimed at examining the effect of compensation plan on workers performance in the Nigerian food and beverage manufacturing companies. The study was carried out with 125 out of the 150 questionnaires that were administered and distributed to the staff of the selected food and beverages companies in Lagos state. Data collected was analyzed using frequency table and percentage analysis while the non-parametric statistical test Chi- square was used to test the formulated hypothesis using STATA 10 data analysis package/software to examine how the selected workers perceived the influence of compensation plan on their Performance. The result of the analysis and hypothesis tested at $5 \%$ level of significance $(p<0.000)$ showed that compensation plan has significant and positive effect on workers performance which will eventually increase the overall performance of the Nigerian foods and beverages industry. Compensation system was also found to be the backbone of all policies concerning the acquisition and utilization of human resources. To this end, it is recommended that food companies should come up with effective compensation plans especially in investing the various aspects of human capital so as to remain competitive and maintain long run survival.
\end{abstract}

Keywords: Compensation Plan, workers Performance, Human Capital, Firm Performance, Nigerian Food and Beverage Industry.

\section{Introduction}

Wages determination and administration otherwise referred to as rewards system has always been a concern of accountants and labour economists. The wage policy of a firm is pronounced in its compensation plan and has been a subject of concern to players in commerce. A well-designed compensation plan is expected to motivate employees, ensure job satisfaction, controls compensation costs, and ensures equity. There is evidence that contingent wage systems affect performance positively (Osterman, 2006). According to Lunenburg, (2011), the Vroom expectancy theory has some important implications for motivating employees as it identifies several important things that can be done to motivate employees by altering the person's effort-toperformance expectancy, performance-to-reward expectancy, and reward valences. Furthermore Lam et. al, (2001) investigated employees' job satisfaction in Hong Kong Hotels and their research results specifically showed that wages is the most important category contributing to job satisfaction while Grund and WestergaardNielsen (2004) examined the interrelation between intra-firm wage increases and firm performance with evidence of positive relationship. One of the components of effective compensation administration program is job pricing which involves establishing rate ranges; that is, minimum, midpoint, and maximum dollar values for each labour grade.

A growing number of employers are incorporating performance-based compensation plans to boost productivity and maximize their return on investment in compensation. These types of plans are designed to reward employees who produce. Some experts argue that traditional salary increases aren't as connected to performance as they should be. By contrast, a well thought out performance-based bonus plan can be tied directly to the results the company sees as valuable. However, developing a performance-based compensation plan could be challenging. One mistake employers often make is setting performance targets too low. Another common mistake is for employers to use the wrong metrics in determining an employee's performance.

Outcomes of worldwide empirical research summarized in recent work of Boselie, Dietz, and Boon (2005) and Katou, and Budhwar (2006) suggest that there are commonalities and also contradictions in Human Resources Management and performance research (Wright and Boswell 2002; Wall and Wood 2005). In another 
study, Delaney and Huselid (1996) found that practices consistent with a high involvement HRM strategy, such as highly selective staffing, incentive compensation, and training, were positively linked to organizational performance. Katou and Budhwar (2006) in their study of 178 Greek manufacturing firms found support with the universalistic model and reported that HRM policies of recruitment, training, promotion, incentives, benefits, involvement and health and safety are positively related to organizational performance. Follow up empirical works have shown reasonably strong, positive relationships between the extent of a firm's adoption of high-involvement HRM strategies and organizational performance (Chadwick and Cappelli 1998; Katou and Budhwar 2007). According to Som (2008), most of the work on HRM and performance has been undertaken in the US and recently in the last decade in UK and as such may not be suitable to explain the relationship in a developing economy like Nigeria. Studies of this nature are new in the context food and beverage industry in Nigeria and shall be focus of the current study.

\section{Statement of the Problem}

Evidence from the literature suggests that employee's compensation plays a key role in any organisation because it is at the heart of the employment relationship and of critical importance to both employees and employers. Employees typically depend on wages, salaries, and so forth to provide a large share of their income and on benefits to provide income and health security. Relying on Vroom expectancy theory, several researches have confirmed positive relationship between rewards system and performance. However, a recent study by Aberdeen Group (2008) reveals there is still much confusion on how to do it right observing a general lack of visibility into many compensation programs being created, and a lot of bad habits being brought into the process. Empirical evidence as to the perceived influence of compensation plan on the performance of food and beverage firms in a developing economy like Nigeria thus becomes imperative. This study remains germane by investigating the influence of compensation plan on the performance of selected employees in the Nigerian quoted foods and beverages industry.

\section{Objectives of the Study}

The main thrust of this paper is to determine the effectiveness of compensation plan on workers performance with the aim of improving the overall organizational performance.

Specifically the paper will provide answers to the following questions:

i. Is there any significant relationship between compensation plan and workers performance?

ii. How does compensation plan affect workers performance?

\section{Research Hypothesis}

Ho: Compensation plan does not positively influence workers performance in the Nigerian foods and beverages industry

\section{Theoretical back ground, Conceptual Clarifications and Literature Review}

Vroom (1964) defines motivation as a process governing choices among alternative forms of voluntary activities, a process controlled by the individual. The individual makes choices based on estimates of how well the expected results of a given behavior are going to match up with or eventually lead to the desired results. Motivation is a product of the individual's expectancy that a certain effort will lead to the intended performance, the instrumentality of this performance to achieving a certain result, and the desirability of this result for the individual, known as valence. The Vroom expectancy theory according to Droar, (2006) emphasizes the needs for organizations to relate rewards directly to performance and to ensure that the rewards provided are those rewards deserved and wanted by the recipients. Expectancy theory is based on four assumptions (Vroom, 1964). One assumption is that people join organizations with expectations about their needs, motivations, and past experiences. These influence how individuals react to the organization. A second assumption is that an individual's behavior is a result of conscious choice. That is, people are free to choose those behaviors suggested by their own expectancy calculations. A third assumption is that people want different things from the organization (e.g., good salary, job security, advancement, and challenge). A fourth assumption is that people will choose among alternatives so as to optimize outcomes for them personally. The expectancy theory based on these assumptions has three key elements: expectancy, instrumentality, and valence. A person is motivated to the degree that he or she believes that (a) effort will lead to acceptable performance (expectancy), (b) performance will be rewarded (instrumentality), and (c) the value of the rewards is highly positive (valence).

The constantly changing business environment requires firms to strive for superior competitive advantages via dynamic business plans which incorporate creativity and innovativeness. This is essentially important for their long term sustainability. Undoubtedly, human resource input plays a significant role in enhancing firms' competitiveness (Barney, 1995). At a glance, substantial studies were carried out on human capital and their implications on firm performance were widely covered and obviously, human capital 
enhancement will result in greater competitiveness and performance (Agarwala et al 2003;Som 2008). Osterman, (2006) concluded in his study that high wages were associated high performance work organizations.

The definition of firm performance could vary from one firm to another. Nonetheless, some clear definitions of firm performance in the context of human capital enhancement could be put forward. In some cases, financial performance measures such as percentage of sales resulting from new products, profitability, capital employed and return on assets (ROA) (Selvarajan et al., 2007; Hsu et al., 2007). Besides, return on investment (ROI), earnings per share (EPS) and net income after tax (NIAT) can also be used as measures of financial performance (Grossman, 2000). Interestingly, researchers also tend to benchmark managerial accounting indicators against the financial measures in six dimension; 'workers compensation' (workers' compensation expenses divided by sales); 'quality' (number of errors in production); 'shrinkage' (e.g. inventory loss, defects, sales return); 'productivity' (payroll expenses divided by output); 'operating expenses' (total operating expenses divided by sales) (Wright et al., 2005). On the other hand, firm performance can also be measured using 'perceived performance approach' (also referred to as subjective performance measure) where Likert-like scaling is used to measure firm performance from the top management perspectives (Selvarajan, 2007).

Evidence from the literature shows that Corporate performance is positively related to the percentage of equity-based compensation to total compensation and that equity-based compensation has a positive impact on the company's financial performance, and higher than on the market performance. According to Adeyemi and Aremu (2008), Organizational effective performance has become a watchword in modern business; as a result there are inexorable pressure for Business Process Re-engineering. Stoffers and Van der Heijden (2009) believed that by stimulating and investing in employability and in the quality of the relationships between employees and supervisors, innovative work behaviour and improved organizational performance can be achieved. According to Marimuthu, Arokiasamy and Ismail, (2009), to develop a competitive advantage, it is important that firms truly leverage on the workforce as a competitive weapon. A strategy for improving workforce productivity to drive higher value for the firms has become an important focus. Firms seek to optimize their workforce through comprehensive human capital development programmes not only to achieve business goals but most important is for a long term survival and sustainability. To accomplish this undertaking, firms will need to invest resources to ensure that employees have the knowledge, skills, and competencies they need to work effectively in a rapidly changing and complex environment.

Although there is a broad assumption that human capital has positive effects on firms' performance, the notion of performance for human capital remains largely untested. Aberdeen used four key performance criteria to distinguish Best-in-Class organizations at designing and managing total compensation programs:

- $90 \%$ of Best-in-Class improved revenue per employee

- $\quad 83 \%$ of Best-in-Class improved labor costs as a percentage of sales

- $73 \%$ of Best-in-Class improved employee job satisfaction

- $64 \%$ of Best-in-Class improved employee retention

Survey results show that the firms enjoying Best-in-Class performance shared several common characteristics:

- $87 \%$ have partially or fully integrated total compensation data collection with other workforce management applications

- $76 \%$ have clearly defined compensation policies

- $75 \%$ have compensation policies clearly communicated to employees

- $70 \%$ have partially or fully automated their data collection (Aberdeen Group Research Report 2008)

\section{The Relationship between Human Capital and Firm Performance}

The human capital focuses two main components which is individuals and organizations. This concept have further been described by Garavan et al., (2001) that human capitals have four key attributes as follows: (1) flexibility and adaptability (2) enhancement of individual competencies (3) the development of organizational competencies and (4) individual employability. It shows that these attributes in turn generate add values to individual and organizational outcomes. There are various findings that incorporate human capital with higher performance and sustainable competitive advantage (Noudhaug, 1998); higher organizational commitment (Iles et al., 1990); and enhanced organizational retention (Robertson et al., 1991).Hence, all this debates fundamentally focuses on individual and organizational performance. From the individual level, Collis and Montgomery (1995) point out that the importance of human capital depends on the degree to which it contributes to the creation of a competitive advantage. From an economic point of view, transaction-costs indicate that firm gains a competitive advantage when they own firm-specific resources that cannot be copied by rivals. Thus, as the uniqueness of human capital increases, firm have incentives to invest resources into its management and the aim to reduce risks and capitalize on productive potentials. Hence, individuals need to enhance their competency skills in order to be competitive in their organizations. 
A study by Bontis and Fitzenz (2002) found that the consequences of human capital management and they established the relationship between human capital management and economic and business outcomes. In this study, a total of 25 firms in the financial services companies were selected. The study measured human capital effectiveness with four metrics; revenue factor, expense factor, income factor and human capital return on investment. The fundamental aspects of any organization are to generate more revenue and income per employee. Human capital has a direct impact on the intellectual capital assets that will yield higher financial results per employee. The development of human capital is positively influenced by the educational level of employees and their overall satisfaction. Therefore, development human capital has a direct impact on ROI of firms. Another study by Seleim, Ashour, and Bontis (2007) analysed on the relationship between human capital and organizational performance of software companies. They found that the human capital indicators had a positive association on organizational performances. These indicators such as training attended and team-work practices, tended to result in superstar performers where more productivity could be translated to organizational performances. This was also supported by Dooley (2000) who found a significant positive correlation between the quality of developers and volume of market shares. Based on the above arguments we can conclude that human capital indicators enhanced the firm performance directly or indirectly.

A causal model using a set of cross-sectional data developed by Selvarajan et al. (2007) indicates that human capital enhancement paves a way for greater innovativeness and this in turn offers positive implications on firm performance. In the meantime, firm performance and human capital could also be viewed in the context of high performance work systems (Hsu et al., 2007). It is argued that the formation and emphasis on the human capital enhancement will result in high performance or rather high performance work systems. Admittedly, human capital development and enhancement in organizations tend to create a significant contribution on organizational competencies and this in turn becomes a great boost for further enhancing innovativeness and the current literature to a large extent supports the fact that firm performance is positively impacted by the presence of human capital practices (Noe et al., 2003; Youndt et al., 2004). Some even endorsed that human capital development is a prerequisite to good financial performance (Delaney \& Huselid, 1996) and in addition, the importance of organizational human capital with regard to firm performance was further supported by Hsu et al. (2007). In addition, evidence shows that the relevance of human capital to firm performance has also become prevalent among the technology-based new ventures, and it seems that the use of human capital tool (emphasizing quality of employees) per say in small technology based new ventures tends to have a great impact on the firms' success (Shrader \& Siegel, 2007).

\section{Compensation Plan, Job Satisfaction and Employees Performance in an Organisation}

The objective of an organization's reward system should be to retain the most valuable employees, and in order to do this, rewards must be distributed in such a way that the more valuable employees will be left with a feeling of satisfaction. To best accomplish this objective, reward levels should be competitive and based upon performance. Among the reasons for basing pay upon performance is the impact that may result from employees' pay satisfaction, job satisfaction, and performance. While there are other reasons for making pay contingent on performance, such as the effect it may have on absenteeism and turnover, these are the most important ones. Indeed, the primary reason for having such a pay system is the potential for the motivation of performance. According to Vroom, (1964) in his theory of expectancy, reward systems that are performancecontingent should lead to higher levels of performance than systems which are not contingent upon performance. There are three key building blocks upon which this theory rests. The first is the effort-toperformance expectancy. Employees have some expectation as to whether or not a particular level of effort will lead to a desired level of performance. Workers have to believe that if they put forth the effort, effective performance will follow. Secondly, employees also have some expectations about the likelihood. For instance Maxham (2003) found that job satisfaction positively correlates with customer satisfaction. He argues that employees who are satisfied in their job will provide better service to customers and customer satisfaction will increase. This will lead to increased sales turnover.

In the last two decades researches have shown that the strategic human resource management (HRM) is likely to be one of the most important determinants of organizational performance as observed by Taylor and Francis (2008). Researchers have built evidence that links HRM practices with corporate performance.(Truss 2001; Paauwe and Boselie 2005; Wright, Snell and Dyer 2005; Som, 2008).

\section{The components of a compensation system}

Literature believed that compensation will be perceived by employees as fair if based on systematic components. Compensation will be perceived as fair if it is comprised of a system of components developed to maintain internal and external equity. Various compensation systems have been developed to determine the value of positions. These systems utilize many similar components including job descriptions, salary ranges/structures, and written procedures. 
The components of a compensation system as gathered from the literature (Truss 2001; Wright, Snell and Dyer 2005; Som, 2008) include:

i. Job Descriptions: this a critical component of both compensation and selection systems, job descriptions define in writing the responsibilities, requirements, functions, duties, location, environment, conditions, and other aspects of jobs. Descriptions may be developed for jobs individually or for entire job families.

ii. Job Analysis: this is the process of analyzing jobs from which job descriptions are developed. Job analysis techniques include the use of interviews, questionnaires, and observation.

iii. Job Evaluation: This is a systematic way of comparing jobs for the purpose of determining appropriate compensation levels for individual jobs or job elements. There are four main techniques: Ranking, Classification, Factor Comparison, and Point Method.

iv. Pay Structures: Useful for standardizing compensation practices. Most pay structures include several grades with each grade containing a minimum salary/wage and either step increments or grade range. Step increments are common with union positions where the pay for each job is pre-determined through collective bargaining.

v. Salary Surveys: Collections of salary and market data: this may include average salaries, inflation indicators, cost of living indicators, salary budget averages. Companies may purchase results of surveys conducted by survey vendors or may conduct their own salary surveys.

\section{Methodology}

The eighteen (18) quoted food and beverages manufacturing companies in Nigeria as at 2013 (www.moneyhub.net/food) made up the population of this research, as shown in Table 1 below. A total of Ten (10) food manufacturing companies (Nestle Nigeria plc, Cadbury plc, Nigeria Flour Mills plc, Nigeria Bottling Company plc, UAC of Nigeria plc, UTC Nigeria plc, 7-up Bottling Company plc, Dangote Flour Mills, Dangote Sugar Refinery plc and Unilever Nigeria plc) were carefully selected for the purpose of the study. The sampling frame of this study comprises of all the entire staff in the relevant departments of the Ten (10) selected food manufacturing companies in Lagos metropolis. Lagos was chosen due to predominance of Business activities and factually all the selected companies have their offices in Lagos. The selection of companies was done using purposive sampling while companies' staffs were selected at random. One hundred and fifty (150) Questionnaires were administered and distributed to the staff of the selected companies. Fifteen (15) staff each was picked from the ten (10) selected companies. One hundred and Twenty five (125) were found useful for the purpose of the study representing $83.3 \%$ of the total questionnaire distributed. The questionnaire consists of questions that are related to compensation plan on workers and performance in the Nigerian Food manufacturing Company as identified in the literature. Likert five point scales ranging from $1-5(1=$ strongly agree and $5=$ strongly disagree) were used as a basis of the questions. Data collected was coded and analyzed using frequency table, percentage and mean score analysis while the non-parametric statistical test (Chi- square) was used to test the formulated hypothesis using STATA 10 data analysis package/software.

Table I: List of quoted food and beverages manufacturing companies sampled for the study:

\begin{tabular}{|c|c|c|}
\hline Numbers of companies & $\begin{array}{c}\text { Sampled/ } \\
\text { Not sampled }\end{array}$ & Location of the Sampled companies \\
\hline 1.7up Bottling Company plc & Sampled & Apapa, Lagos,Nigeria. \\
\hline 2. Cadbury Nigeria plc & sampled & Lateef Jakande Road, Ikeja,Lagos,Nigeria \\
\hline 3. Big Treat Nigeria plc & Not Sampled & ******************************************* \\
\hline 4. Dangote Four Mills plc & Sampled & Ikoyi,Lagos Nigeria \\
\hline 5. Dangote Sugar Refinery & sampled & Apapa Wharf,Lagos, Nigeria \\
\hline 6. Ferdinand oil mills plc & Not Sampled & 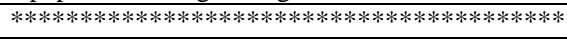 \\
\hline 7. Flour mills Nigeria plc & Sampled & 2,Old Dock Road, Apapa,lagos, Nigeria \\
\hline 8. Foremost Dairies plc & Not Sampled & 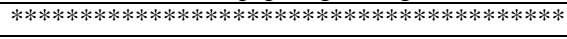 \\
\hline 9. Honey well Nigeria plc & Not Sampled & 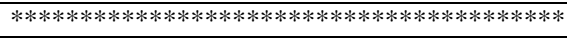 \\
\hline 10. National Salt Company Nigeria plc & Not sampled & 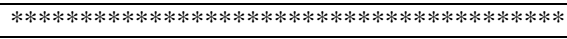 \\
\hline 11.Nigeria Bottling Company plc & sampled & Agidingbin, Ikeja ,Lagos,Nigeria \\
\hline 12. Northern Nigeria Flour mills plc & Not Sampled & 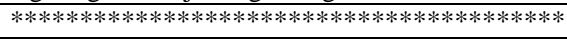 \\
\hline 13. PS Mandrides \& company plc & Not Sampled & 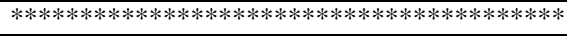 \\
\hline 14.UAC of Nigeria plc & Sampled & Odunlami Street, Marina, Lagos, Nigeria \\
\hline 15. Unilever Nigeria plc & Sampled & Oregun, Lagos, Nigeria \\
\hline 16.Union Dicon Salt plc & Not Sampled & ******************************************** \\
\hline 17. UTC Nigeria plc & Sampled & 27/29, Creek Road, Apapa, Lagos, Nigeria \\
\hline 18.Nestle Nigeria plc & Sampled & Ilupeju, Lagos, Nigeria \\
\hline
\end{tabular}

Source: NSE report as at Friday November2013. (www.moneyhub.net/food ).

Number of Quoted and Sampled companies $=10$

Number of Quoted and Not Sampled companies $=8$ 


\section{Results and Discussions}

The result of the analysis of compensation plan effect on workers performance in the Nigerian food and beverages manufacturing companies was presented in Table II below. From the table, majority of the respondents $(76 \%)$ of the total respondents agreed that Nigerian food and beverages industry has an established compensation Policy with $24 \%$ undecided. This shows that Nigerian food and beverages industry has an established compensation Policy. Similarly, the table indicates that large number of respondents, $(89.60 \%)$ agreed that compensation plan has great value on the organization targeted goal. Also, a large number of respondents $(76 \%)$ agreed that Organisation compensation plan is all inclusive, both in cash and kind. Workers strike is not rampant in manufacturing industry due to good compensation package by the company $(88 \%)$ with $12 \%$ undecided. An increase in workers welfare package leads to workers job output improvement $(76 \%)$ with $4 \%$ undecided and only $20 \%$ disagreed. The result that compensation package enhances higher performance is in line with Vroom expectancy theory as expanded in the subsequent works of Droar (2006), Lam et al (2001), and Maxham, (2003) which emphasize the needs for organizations to relate rewards directly to performance and to ensure that the rewards provided are those rewards deserved and wanted by the recipients. Also, $64 \%$ of the respondents strongly agreed that with good compensation plan no workers will leave job before retirement age, $20 \%$ disagreed to it, while $16 \%$ were undecided. Likewise, $64.8 \%$ of the respondents agreed that employees of an organisation are instrumental to survival of the organization with 11.2 $\%$ disagreed and $24 \%$ undecided. A good compensation plan will improve organization performance $(74.4 \%)$ with $25.6 \%$ undecided. The table also indicates that $64 \%$ of the respondents agreed that Workers productivity will be greatly enhanced with good reward system. However $25.6 \%$ disagreed, while $10.40 \%$ were undecided. This corroborates earlier findings in developed world by Hsu et al (2007), Noe et al (2007), Youndt et al (2004) and Lunenburg, (2011) that the formation and emphasis on the human capital enhancement will result in high performance work systems.

Finally $76 \%$ of the respondents disagreed that foods and beverage industry always retrench their workers with only $24 \%$ agreed, meaning that retrenchment is not rampant in the foods and beverages industry in Nigeria.

Table II: Distribution of Responses on Staff's Perception of Compensation Plan impact on Workers Performance in the Nigerian Manufacturing Industry.

\begin{tabular}{|l|l|l|l|l|l|l|l|}
\hline $\mathbf{S} / \mathbf{N}$ & ITEMS & $\mathbf{S A}$ & $\mathbf{A}$ & $\mathbf{D}$ & $\mathbf{S D}$ & U & TOTAL \\
\hline 1 & $\begin{array}{l}\text { Nigeria manufacturing company has an } \\
\text { established compensation Policy }\end{array}$ & $\begin{array}{l}40 \\
(32.00)\end{array}$ & $\begin{array}{l}55 \\
(44.00)\end{array}$ & $\begin{array}{l}0 \\
(0)\end{array}$ & $\begin{array}{l}0 \\
(0)\end{array}$ & $\begin{array}{l}30 \\
(24.00)\end{array}$ & $\begin{array}{l}125 \\
(100)\end{array}$ \\
\hline 2 & $\begin{array}{l}\text { Compensation plan has great value on the } \\
\text { organization targeted goal }\end{array}$ & $\begin{array}{l}88 \\
(70.40)\end{array}$ & $\begin{array}{l}24 \\
(19.20)\end{array}$ & $\begin{array}{l}12 \\
(9.60)\end{array}$ & $\begin{array}{l}0 \\
(0)\end{array}$ & $\begin{array}{l}1 \\
(0.80)\end{array}$ & $\begin{array}{l}125 \\
(100)\end{array}$ \\
\hline 3 & $\begin{array}{l}\text { Organisation compensation plan is all inclusive, } \\
\text { both in cash and kind }\end{array}$ & $\begin{array}{l}70 \\
(56.00)\end{array}$ & $\begin{array}{l}25 \\
(20.00)\end{array}$ & $\begin{array}{l}0 \\
(0)\end{array}$ & $\begin{array}{l}30 \\
(24.00)\end{array}$ & $\begin{array}{l}0 \\
(0)\end{array}$ & $\begin{array}{l}125 \\
(100)\end{array}$ \\
\hline 4 & $\begin{array}{l}\text { Workers strike is not rampant in manufacturing } \\
\text { company due to good compensation package by } \\
\text { the company }\end{array}$ & $\begin{array}{l}70 \\
(56.00)\end{array}$ & $\begin{array}{l}40 \\
(32.00)\end{array}$ & $\begin{array}{l}0 \\
(0)\end{array}$ & $\begin{array}{l}0 \\
(0)\end{array}$ & $\begin{array}{l}15 \\
(12.00)\end{array}$ & $\begin{array}{l}125 \\
(100)\end{array}$ \\
\hline 5 & $\begin{array}{l}\text { An increase in workers welfare package lead to } \\
\text { workers job output improvement. }\end{array}$ & $\begin{array}{l}70 \\
(56.00)\end{array}$ & $\begin{array}{l}25 \\
(20.00)\end{array}$ & $\begin{array}{l}10 \\
(8.00)\end{array}$ & $\begin{array}{l}15 \\
(12.00)\end{array}$ & $\begin{array}{l}5 \\
(4.00)\end{array}$ & $\begin{array}{l}125 \\
(100)\end{array}$ \\
\hline 6 & $\begin{array}{l}\text { With good compensation plan no workers will } \\
\text { leave job before retirement age }\end{array}$ & $\begin{array}{l}50 \\
(40.00)\end{array}$ & $\begin{array}{l}30 \\
(24.00)\end{array}$ & $\begin{array}{l}0 \\
(0)\end{array}$ & $\begin{array}{l}25 \\
(20.00)\end{array}$ & $\begin{array}{l}20 \\
(16.00)\end{array}$ & $\begin{array}{l}125 \\
(100)\end{array}$ \\
\hline 7 & $\begin{array}{l}\text { Employees of an organisation are instrumental } \\
\text { to survival of the organization }\end{array}$ & $\begin{array}{l}55 \\
(44.00)\end{array}$ & $\begin{array}{l}26 \\
(20.80)\end{array}$ & $\begin{array}{l}0 \\
(0)\end{array}$ & $\begin{array}{l}14 \\
(11.20)\end{array}$ & $\begin{array}{l}30 \\
(24.00)\end{array}$ & $\begin{array}{l}125 \\
(100)\end{array}$ \\
\hline 8 & $\begin{array}{l}\text { A good compensation plan does not improve } \\
\text { organization performance }\end{array}$ & $\begin{array}{l}0 \\
(0)\end{array}$ & $\begin{array}{l}0 \\
(0)\end{array}$ & $\begin{array}{l}59 \\
(47.20)\end{array}$ & $\begin{array}{l}34 \\
(27.20)\end{array}$ & $\begin{array}{l}32 \\
(26.60)\end{array}$ & $\begin{array}{l}125 \\
(100)\end{array}$ \\
\hline 9 & $\begin{array}{l}\text { Workers productivity will be greatly enhanced } \\
\text { with good reward system }\end{array}$ & $\begin{array}{l}53 \\
(42.40)\end{array}$ & $\begin{array}{l}27 \\
(21.60)\end{array}$ & $\begin{array}{l}12 \\
(9.60)\end{array}$ & $\begin{array}{l}20 \\
(16.00)\end{array}$ & $\begin{array}{l}13 \\
(10.40)\end{array}$ & $\begin{array}{l}125 \\
(100)\end{array}$ \\
\hline 10 & $\begin{array}{l}\text { Foods and beverage industry always retrench } \\
\text { their workers }\end{array}$ & $\begin{array}{l}10 \\
(8.00)\end{array}$ & $\begin{array}{l}20 \\
(16.00)\end{array}$ & $\begin{array}{l}55 \\
(44.00)\end{array}$ & $\begin{array}{l}40 \\
(32.00)\end{array}$ & $\begin{array}{l}0 \\
(0)\end{array}$ \\
\hline
\end{tabular}

Note: the bracket Figures indicate the percentage $\&$ figure not bracket indicate the frequency

Source: Computations and Output of STATA10 based on Authors' Field Survey (2013).

\section{Test of hypothesis}

$\mathbf{H}_{\mathbf{0}}$ : Compensation plan has no positive effect on workers performance in the Nigerian foods and beverages industry

The result of the hypothesis tested using Stata 10 statistical package was presented in Table III below. The chi-squares calculated (X2-cal) are greater than chi-square tabulated (X2-tab) which makes all the figures to be highly statistically significant with the probability of $F=0.000$. Collectively; we reject null hypothesis stated earlier but accept alternative hypothesis that compensation plan has positive effect on workers performance in the Nigerian foods and beverages industry 
Table III: Chi-square Analysis table of Compensation Plan Effect on Workers Performance in the Nigerian Food Manufacturing Company

\begin{tabular}{|c|c|c|c|c|}
\hline S/N & Relationship & Pearson Chi-Square (Value & Pr (Value) & Remark \\
\hline 1 & Q1 VS Q2 & 100.3027 & 0.000 & Significant \\
\hline 2 & Q1 VS Q3 & 157.4675 & 0.000 & Significant \\
\hline 3 & Q1 VS Q4 & 97.0982 & 0.000 & Significant \\
\hline 4 & Q1 VS Q6 & 168.1818 & 0.000 & Significant \\
\hline 5 & Q1 VS Q7 & 191.1157 & 0.000 & Significant \\
\hline 6 & Q1 VS Q8 & 116.0760 & 0.000 & Significant \\
\hline 7 & Q1 VS Q9 & 180.6207 & 0.000 & Significant \\
\hline 8 & Q2 VS Q3 & 107.3895 & 0.000 & Significant \\
\hline 9 & Q2 VS Q4 & 158.6806 & 0.000 & Significant \\
\hline 10 & Q2 VS Q5 & 174.9242 & 0.000 & Significant \\
\hline 11 & Q2 VS Q6 & 146.4915 & 0.000 & Significant \\
\hline 12 & Q2 VS Q7 & 117.5979 & 0.000 & Significant \\
\hline 13 & Q2 VS Q8 & 93.4343 & 0.000 & Significant \\
\hline 14 & Q2 VS Q9 & 232.3232 & 0.000 & Significant \\
\hline 15 & Q8 VS Q10 & 156.9562 & 0.000 & Significant \\
\hline 16 & Q5 VS Q8 & 122.7891 & 0.000 & Significant \\
\hline 17 & Q4 VS Q8 & 109.6939 & 0.000 & Significant \\
\hline 18 & Q8 VS Q9 & 212.3352 & 0.000 & Significant \\
\hline 19 & Q4 VS Q5 & 211.8056 & 0.000 & Significant \\
\hline 20 & Q7 VS Q8 & 216.1198 & 0.000 & Significant \\
\hline 21 & Q8 VS Q10 & 156.9562 & & \\
\hline
\end{tabular}

Source: Computations and Out-Put of STATA 10 based on Author's Field Survey `(2013).

\section{Conclusion and Recommendation}

This study concludes that there is significant relationship between compensation plan and employee performance in the Nigerian foods and beverages industry. Findings further confirm that an effective compensation system is the backbone of all policies concerning the acquisition and utilization of human resources. In view of the above finding the following recommendation were made:

i. Companies should come up with some effective compensation plans especially in investing the various aspects of human capital as not only does it direct firms to attain greater performance but also it ensures firms to remain competitive for their long term survival.

ii. More efforts should be directed towards training and capacity building so that companies gain much from staff retention arising from good compensation policy

\section{References}

[1]. Aberdeen (2008) Group. www.aberdeen.com

[2]. Adeyemi, S, \& Aremu, M . A (2008), "Impact Assessment of Business Process Reengineering on Organisational Performance", European Journal of Social Sciences - Volume 7, Number 1 (2008)

[3]. Agarwala, T. (2003). Innovative human resource practices and organizational commitment: An empirical investigation. International Journal of Human Resource Management, 14(2), 175-197.

[4]. Boselie, P., Dietz, G., and Boon, C. (2005), 'Commonalities and Contradictions in HRM and Performance Research,' Human Resource Management Journal, 15, 3, 67-94.

[5]. Bontis, N. \& Fitzenz, J. (2002). Intellectual capital ROI: A current map to human capital antecedents and consequences. Journal of Intellectual Capital, 3(3), 223-247.

[6]. Chadwick, C. (2007). Examining non-linear relationships between human resource practices and manufacturing performance. Industrial and Labor Relations Review, 60(4), 499-521.

[7]. Collis, D.J. and Montgomery, C.A. (1995). Competing on resources: Strategy in the 1990s. Harvard Business Review. July \& August, pp.118-28.

[8]. Delaney, J.T., and Huselid, M.A. (1996), 'The Impact of Human Resource Management Practices on Perceptions of Organizational Performance,' Academy of Management Journal, 39, 4, 949-969.

[9]. Droar, D. (2006). Expectancy theory of motivation. Retrieved October 2, 2010, from http://www.arrod.co.uk/archive/concept_vroom.php

[10]. Dooley, E. (2000). Intellectual capital in the software industry: An empirical test. PhD dissertation, College of Business Administration, University of Washington, Tacoma, WA.

[11]. Garavan, T. N., Morley, M., Gunnigle, P., \& Collins, E. (2001). Human Capital accumulation: The role of human resource development. Journal of European Industrial Training, 25(2/3/4), 48-68.

[12]. Grossman, R. J. (2000). Measuring up: Appropriate metrics help HR prove its worth. HR Magazine, 45(1), $28-35$.

[13]. Grund, C and Westergaard-Nielsen (2004), The Dispersion of Employees' Wage Increases and Firm Performance November 2004; DISCUSSION PAPER SERIESIZA DP No. 1402; Forschungsinstitut zur Zukunft der Arbeit Institute for the Study of LaborLam, T., Zhang,

[14]. Hsu, I. C., Lin, C. Y. Y., Lawler, J. J., \& Wu, S. H. (2007). Toward a model of organizational human capital development: Preliminary evidence from Taiwan. Asia Pacific Business Review, 13(2), 251-275.

[15]. Huang, G. Z. D., Roy, M. H., Ahmed, Z. U., Heng, J. S. T. \& Lim, J. H. M. (2002). Benchmarking the human capital strategies of MNCs in Singapore. Benchmarking, 9(4), 357-373.

[16]. Katou, A., and Budhwar, P. (2006), 'The Effect of Human Resource Management Systems On Organizational Performance: Test of a Mediating Model,' International Journal of Human Resource Management, 17, 7, 1223-1253. 
[17]. Katou, A., and Budhwar, P. (2007), 'The Effect of Human Resource Management Policies On Organizational Performance in Greek Manufacturing Firms,' Thunderbird International Business Review, 49, 1, 1-35.

[18]. Lunenburg, F. C (2011),Expectancy Theory of Motivation: Motivating by Altering Expectations; International Journal of Management, Business, and Administration Volume 15, Number 1, 2011

[19]. Marimuthu, M, Irokiasamy, 1, and Ismail, M (2009), Human capital development and its impact on firm performance: evidence from developmental economics, The Journal of International Social Research Volume 2 / 8 Summer 200

[20]. Maxham, J. A. N., R. (2003). Firms reap what they sow: The effects of shared values and peceived organizational justice on customers' evaluations of complaint handling. Journal of Marketing, 67(1), 46-62.Noe, R. A., Hollenbeck, J. R., Gerhart, B., \& Wright, P. M. (2003). Human resource management: Gaining a competitive advantage (4th ed.). Boston: McGraw-Hill.

[21]. Nordhaug, O. (1998). Competencies specificities in organizations. International Studies of Management and Organisation, 28(1), 829.

[22]. Osterman ,P (2006), The Wages Effect of High Performance Work Organisations in Manufacturing; Industrial and Labour Relation Review, Volume 59 No. 2; pp187-204; http;//www.jstor.org

[23]. Organization for Economic Co-operation and Development (OECD) (2001). The Well- Being of Nations: The Role of Human and Social Capital. Paris: OECD.

[24]. Paauwe, J., and Boselie, P. (2005), 'Best Practices . . in spite of Performance: Just a Matter of Imitation?,' International Journal of Human Resource Management, 16, 987-1003.

[25]. Seleim, A., Ashour, A., \& Bontis, N. (2007). Human capital and organizational performance: A study of Egyptian software companies. Management Decision. 45(4), 789-801.

[26]. Selvarajan, T. T., Ramamoorthy, N., Flood, P. C., Guthrie, J. P., MacCurtain, S., \& Liu, W. (2007). The role of human capital philosophy in promoting firm innovativeness and performance: Test of a causal model. International Journal of Human Resource Management, 18(8), 1456-1470.

[27]. Stoffers, J. M.M , and van der Heijden (2009), Towards an HRM Model predicting Organisational Performance by Enhancing Innovative Work Behaviour: A Study among Dutch SMEs in the Province of Limburg, Business Leadership Review Vi:IV www.mbaworld.com/blr October 2009, pp 1-13, Association of MBAs Maastricht School of Management, Open University of the Netherlands, University of Twente

[28]. Truss, C. (2001), 'Complexities and Controversies in Linking HRM with Organizational Outcomes,' Journal of Management Studies, 38, 8, 1121-1149.

[29]. Wall, T.D., and Wood, S.J. (2005), 'The Romance of Human Resource Management and Business Performance, and the Case of Big Science,' Human Relations, 58, 4, 429-462.

[30]. Wright, P.M., Snell, S.A., and Dyer, L. (2005), 'New Models of Strategic HRM in a Global Context,' International Journal of Human Resource Management, 16, 875-881

[31]. Taylor \& Francis 2008) : The International Journal of Human Resource Management,Vol. 19, No. 7, July 2008, 1278-1297, http://www.informaworld.com.

[32]. Vroom, V. H. (1964). Work and motivation. San Francisco, CA: Jossey-Bass.

[33]. Youndt, M.A., Snell, S.A., Dean, J.W., and Lepak, D.P. (1996), 'Human Resource Management, Manufacturing Strategy and Firm Performance,' Academy of Management Journal, 39, 4, 836-866. 